\title{
Validitas Pengembangan Modul Pembelajaran Biologi Berorientasi Mind map dengan Variasi Tebak Kata untuk Peserta Didik Kelas VIII SMP
}

\author{
Darmanella Dian Eka Wati ${ }^{1)}$, Ratih Komala Dewi ${ }^{2)}$ \\ ${ }^{1,2)}$ Staf Pengajar Program Studi Pendidikan Biologi, FKIP Universitas Mahaputra Muhammad Yamin \\ eka22darmanella@gmail.com
}

\begin{abstract}
Teacher's success in implementing learning depends on the insight, knowledge, understanding and creativity level in managing teaching materials. One form to process subject matter is by using the module. Module oriented Mind map (MM) equipped with Words Guess game will become more interesting and can develop students' interest and creativity. The development of this module must pass the validity test stage by the validator before it is used in the learning process. The purpose of this research is to know the developed validity of Biology Learning Module, which orients Mind map (MM) equipped with a Words Guess game in class VIII SMP. This research is a development research (Research and Development) using 4-D model consisting of 4 stages of define, design, develop, and disseminate. By far, this research only reaches the development stage which is at validity test phase. Based on validity test results by 4 validates indicate that developed learning module Biology oriented Mind map with Words Guess variation is a very good category to be used in the learning process.
\end{abstract}

Keywords: Develop, Module, Mind map, Words Guess

his is an open access article distributed under the Creative Commons 4.0 Attribution License, which permits unrestricted use, distribution, and reproduction in any medium, provided the original work is properly cited. @2018 by author and Universitas Negeri Padang.

\section{PENDAHULUAN}

Pendidikan merupakan salah satu hal yang dinilai semakin penting ketika seseorang harus memasuki kehidupan di masyarakat dan dunia kerja untuk menghadapi berbagai problema yang ditemukan dalam kehidupan sehari-hari. Pentingnya pendidikan ini mengandung konsekuensi bahwa penyempurna an atau perbaikan pendidikan diperlukan secara terus-menerus untuk mengantisipasi kebutuhan dan tantangan masa depan dan diselaraskan dengan perkembangan kebutuhan dunia usaha, perkembangan dunia kerja serta perkembangan ilmu pengetahuan, teknologi dan seni.

Memasuki abad ke-21, sistem pendidikan nasional menghadapi tantangan yang sangat kompleks dalam menyiapkan kualitas sumber daya manusia (SDM) yang mampu bersaing di era global. Salah satu upaya yang tepat untuk membangun SDM yang bermutu tinggi adalah melalui pendidikan. Peningkatan kualitas SDM melalui pendidikan sudah diupa-yakan oleh pemerintah melalui adanya penyelenggaraan perbaikan-perbaikan dan peningkatan mutu pendidikan pada berbagai jenis dan jenjang. Namun fakta di lapangan masih belum menunjukkan hasil yang memuaskan.

Masalah utama dalam pembelajaran pada pendidikan formal dewasa ini adalah masih rendahnya daya serap peserta didik. Hal ini dapat dilihat dari rata-rata hasil belajar peserta didik yang senantiasa masih sangat memprihatin kan. Salah satu faktor penyebab rendahnya hasil belajar peserta didik adalah kurangnya minat peserta didik untuk membaca sumber belajar baik sebelum belajar, saat proses pembelajaran maupun untuk membaca ulang materi yang sudah dipelajari di sekolah. Sehingga ketika diadakan ulangan ataupun ujian mereka kesulitan dalam menjawab soal-soal yang diberikan.

Berdasarkan hasil wawancara dengan beberapa guru Biologi di sekolah yang di observasi mengungkapkan bahwa minat baca peserta didik termasuk rendah, hanya peserta didik yang tergolong rajin dan pintar yang memiliki minat baca yang cukup baik. Beberapa peserta didik lainnya melakukan aktivitas lain ketika diminta membaca buku cetak, seperti ngobrol dengan teman, hanya melihat-lihat gambar, memainkan alat tulis, menulis-nulis atau membuat coretan atau mengambar sesuatu dan lain sebagainya. Hal ini merupakan indikator bahwa kurangnya minat baca dan ketertarikan peserta didik untuk membaca buku yang diminta. Kurangnya minat baca peserta didik bisa juga disebabkan oleh kurang menariknya materi yang akan mereka baca. 
Pengorganisasian atau pengemasan materi pelajaran sangat mempengaruhi proses pem belajaran yang akan terselenggarakan. Materi pelajaran yang ada di dalam buku perlu diolah lagi oleh guru sehingga mudah dipahami oleh peserta didik. Keberhasilan seorang guru dalam melaksanakan pembelajaran tergantung pada wawasan, pengetahuan, pemahaman dan tingkat kreativitasnya dalam mengelola materi ajar. Salah satu bentuk pengolahan materi pelajaran adalah modul.

Modul menurut Rayandra (2012) merupa kan salah satu bentuk bahan ajar berbasis cetakan yang dirancang untuk belajar secara mandiri oleh peserta pembelajar yang dilengkapi dengan petunjuk untuk belajar sendiri. Modul ini mestinya dirancang semenarik mungkin sehingga bisa memancing minat peserta didik untuk membacanya. Modul yang ada saat ini sudah membantu peserta didik dalam belajar, tetapi sayangnya saat ini masih lebih mengembangkan kemampuan otak kiri peserta didik yaitu yang lebih mengembangkan logika peserta didik tetapi masih kurang dalam mengembangkan kreativitas peserta didik. Oleh karena itu perlu dikembangkan modul yang selain mengembangkan kemampuan logika juga mengembangkan kemampuan kreatifitas peserta didik.

Kreativitas menurut Utami Munandar dalam Muhammad (2009) adalah kemampuan yang mencerminkan kelancaran, keluwesan, dan orisinalitas dalam berpikir serta kemampuan untuk mengelaborasi suatu gagasan. Mind map merupakan salah satu sarana untuk menggali kreativitas. Keterampilan kreatif yang kuat akan meningkatkan kemampuan untuk mengingat segala sesuatunya. Seperti yang diungkapkan oleh Buzan (2005) bahwa Mind map adalah cara termudah untuk menempatkan informasi ke dalam otak dan mengambil informasi ke luar dari otak, Mind map adalah cara mencatat yang kreatif, efektif dan secara harfiah akan memetakan pikiran-pikiran kita.

Berdasarkan hasil wawancara dengan guru dan peserta didik di sekolah yang diobservasi ditemukan bahwa Mind map jarang sekali digunakan dalam proses pembelajaran, bahkan ada peserta didik yang tidak tahu apa itu Mind map. Hal ini sangat disayangkan karena ada banyak kelebihan yang bisa kita dapatkan jika kita belajar dengan menggunakan Mind map diantaranya yaitu dapat membantu peserta didik dalam merencana, berkomunikasi, menjadi lebih kreatif, dapat menghemat waktu, mengingat dengan lebih baik, belajar lebih cepat dan efisien. Oleh karena itu, saya ingin sekali mengenalkan Mind map kepada peserta didik melalui pengembangan modul berorientasi Mind map.

Modul juga perlu dilengkapi dengan kegiatan evaluasi. Jika proses evaluasi ini dibuat dalam bentuk permainan tebak kata tentu akan menjadi lebih menarik bagi peserta didik. Tebak kata merupakan suatu model pembelajaran yang menyajikan istilah-istilah yang akan ditebak menyerupai permainan yang dapat memancing minat belajar peserta didik. Kelebihan model pembelajaran ini sangat menarik sehingga setiap peserta didik ingin mencobanya (Taufina, 2009). Modul yang berorientasi Mind map dan di lengkapi dengan permainan tebak kata akan menjadi lebih menarik dan dapat mengembang kan minat dan kreatifitas peserta didik. Oleh karena itu perlu dirancang modul pembelajaran Biologi yang berorientasi Mind map dan dilengkapi dengan permainan tebak kata di kelas VIII SMP.

Modul pembelajaran yang dikembang-kan haruslah terlebih dahulu dilakukan uji kelayakan atau uji validitasnya agar dapat diketahui apakah modul layak atau valid untuk digunakan dalam proses pembelajaran. Oleh karena itu tujuan dari penelitian ini adalah untuk mengetahui validitas modul pembelajaran Biologi yang berorientasi Mind map dengan variasi tebak kata di SMP kelas VIII. Manfaat dari penelitian ini adalah menghasilkan modul pembelajaran Biologi yang berorientasi Mind map dengan variasi tebak kata yang valid untuk digunakan dalam proses pembelajaran di SMP kelas VIII.

\section{METODE PENELITIAN}

Penelitian ini termasuk jenis penelitian pengembangan (Research and Development). dengan model 4-D (four-D models), yang terdiri dari empat tahap. Menurut Thiagarajan (1974), keempat tahap itu adalah pendefinisian (define), perancangan (design), pengembangan (develop) dan penyebaran (disseminate). Penelitian ini merupakan lanjutan dari penelitian sebelumnya yaitu tahap define dan design dari pengembang an modul pembelajaran Biologi yang ber orientasi Mind map dengan variasi tebak kata. Pada artikel ini penelitian yang dilakukan adalah pada tahap develop yaitu tahap uji validasi. 
Validasi menurut Rayandra (2012) adalah proses permintaan persetujuan atau pengesahan terhadap kesesuaian modul dengan kebutuhan yang dilakukan dengan melibatkan pihak praktisi yang ahli sesuai dengan bidang-bidang terkait dalam modul. Uji validitas modul dilakukan oleh 4 validator, yang terdiri dari satu orang dosen Biologi untuk memvalidasi tentang kelayakan isi/materi dari modul, satu orang dosen Bahasa untuk memvalidasi tentang kelayakan bahasa dari modul, satu orang dosen bidang Media untuk memvalidasi tentang kelayakan kegrafikan dari modul, dan satu orang praktisi yaitu guru IPA untuk memvalidasi tentang kelayakan penyajian dari modul. Data uji validitas diambil melalui pengisian instrumen angket validitas modul oleh masing-masing validator. Data validasi oleh validator diambil melalui instrumen berupa angket validasi. Data hasil angket validasi diolah secara deskriptif yaitu dengan menggunakan teknik persentase.

\section{HASIL DAN PEMBAHASAN}

Modul pembelajaran Biologi berorien-tasi Mind map dengan variasi Tebak kata ini sebelumnya sudah melewati tahap pendefenisian (define) yaitu berupa analisis ujung depan, analisis peserta didik, analisis tugas, analisis konsep dan analisis tujuan pembelajaran. Berdasarkan hasil analisis pada tahap define maka dilakukanlah perancangan modul (tahap design) yang terdiri dari cover, kata pengantar, daftar isi, petunjuk belajar, lembar kompetensi, tujuan pembelajaran, uraian materi, lembar kegiatan peserta didik berupa kegiatan melengkapi Mind map dan evaluasi berupa tebak kata, uji kompetensi dan kunci jawaban. Hasil rancangan awal ini kemudian di serahkan kepada validator untuk dilakukan uji validasi (tahap develop).

a. Data uji validitas modul oleh ahli materi dapat kita lihat pada tabel berikut ini.

Tabel 1. Rata-rata Validitas Modul oleh Ahli Materi

\begin{tabular}{|c|c|c|c|}
\hline $\begin{array}{c}\text { Aspek } \\
\text { yang } \\
\text { dinilai }\end{array}$ & $\begin{array}{c}\text { Rata- } \\
\text { rata } \\
\text { Validitas }\end{array}$ & $\begin{array}{c}\text { Persen } \\
\text { tase } \\
\text { Validitas } \\
(\%)\end{array}$ & Kategori \\
\hline $\begin{array}{c}\text { Kelaya- } \\
\text { kan isi }\end{array}$ & 3,42 & 85,42 & Baik \\
\hline $\begin{array}{c}\text { Mind } \\
\text { map }\end{array}$ & 3,80 & 95,00 & $\begin{array}{c}\text { Sangat } \\
\text { baik }\end{array}$ \\
\hline Tebak & 3,80 & 95,00 & Sangat \\
\hline
\end{tabular}

\begin{tabular}{|c|c|c|c|}
\hline Kata & & & baik \\
\hline Rata-rata & 3,59 & 89,77 & $\begin{array}{c}\text { Sangat } \\
\text { baik }\end{array}$ \\
\hline
\end{tabular}

Berdasarkan data uji validasi oleh ahli materi dapat kita lihat bahwa modul yang dikembangkan dinilai memiliki validitas pada aspek kelayakan isi dengan nilai rata-rata 3,42, dan termasuk kategori baik. Kelayakan isi ini ditinjau dari kesesuaian materi dengan KD yaitu kelengkapan materi, keluasan dan kedalaman materi sesuai dengan apa yang diminta oleh KD. Menurut Permendikbud Nomor 24 tahun 2016, Kompetensi Dasar merupakan kemampuan dan materi minimal yang harus dicapai peserta didik untuk suatu mata pelajaran pada masing-masing satuan pendidikan yang mengacu pada kompetensi inti.

Permendikbud Nomor 21 tahun 2016 juga mengungkapkan bahwa ruang lingkup materi yang spesifik untuk setiap mata pelajaran dirumuskan berdasarkan tingkat kompetensi dan kompetensi inti untuk mencapai kompetensi lulusan minimal pada jenjang dan jenis pendidikan tertentu. Artinya untuk menyusun sebuah materi pada modul kita harus mengacu kepada kompetensi dasar dan kompetensi inti.

Modul yang dikembangkan juga sudah memiliki keakuratan materi yang ditinjau dari keakuratan konsep dan definisi, data dan fakta, contoh dan kasus, gambar, diagram dan ilustrasi. Gambar, ilustrasi dan contoh yang digunakan adalah yang ada dan dekat dengan kehidupan sehari-hari. Modul ini juga dinilai dapat mendorong rasa ingin tahu peserta didik melalui kegiatan melengkapi Mind map dan tebak kata. Ella (2007) mengungkapkan bahwa setiap materi yang diberikan kepada peserta didik harus mampu menumbuhkembangkan rasa ingin tahu, sehingga memunculkan dorongan untuk mengembangkan sendiri kemampuan mereka untuk menguasai kompetensi tertentu dan untuk belajar lebih lanjut.

Pada aspek Mind map memiliki rata-rata validitas 3,80 dan termasuk kategori sangat baik. Mind map yang disajikan pada modul dinilai sudah memiliki struktur dan penyajian konsep yang benar. Struktur Mind map pada modul dibuat dengan menggunakan software iMind Map karya Tony Buzan. Konsep-konsep dari materi pembelajaran disajikan dalam bentuk Mind map dengan meletakkan konsep utama pada bahagian tengah kertas, dan uraian konsep utama dibuat dalam bentuk cabang-cabang yang 
berwarna dan divariasikan dengan gambar pendukung.

Mind map juga dapat merangsang minat belajar, karena Mind map lebih merangsang secara visual dengan adanya kombinasi warna, gambar dan cabang-cabang melengkung. Ada nya Mind map pada modul juga dapat memudahkan peserta didik dalam berpikir dan mengingat. Hal ini sesuai dengan apa yang diungkapkan oleh Buzan (2009) bahwa Mind map merupakan peta rute yang hebat bagi ingatan, yang memungkinkan bagi kita menyusun fakta dan pikiran sedemikian rupa sehingga cara kerja alami otak dilibatkan sejak awal akibatnya mengingat informasi dapat menjadi lebih mudah.

Pada modul juga divariasikan dengan kegiatan tebak kata. Validator menilai untuk aspek tebak kata ini memiliki nilai rata-rata validitasnya adalah 3,64 dan termasuk kategori sangat baik. Artinya tebak kata yang disajikan pada modul sudah memiliki struktur yang benar dan sudah memiliki kesesuaian antara kartu deskripsi dengan kartu jawaban. Tebak kata dinilai dapat membantu proses evaluasi dan memotivasi peserta didik untuk melakukan evaluasi serta menjadi lebih menyenangkan bagi peserta didik. Rayandra (2012) mengungkapkan bahwa modul yang dikembangkan harus mampu meningkatkan motivasi peserta didik dan efektif dalam mencapai kompetensi yang diharapkan sesuai dengan tingkat kompleksitasnya.

b. Data uji validitas modul oleh ahli bahasa dapat kita lihat pada tabel berikut ini.

Tabel 2. Rata-rata Validitas Modul oleh Ahli Bahasa

\begin{tabular}{|l|c|c|c|}
\hline $\begin{array}{c}\text { Aspek yang } \\
\text { dinilai }\end{array}$ & $\begin{array}{c}\text { Rata- } \\
\text { rata } \\
\text { Validi- } \\
\text { tas }\end{array}$ & $\begin{array}{c}\text { Persenta- } \\
\text { se Vali- } \\
\text { ditas (\%) }\end{array}$ & $\begin{array}{c}\text { Kate- } \\
\text { gori }\end{array}$ \\
\hline Lugas & 3,33 & 83,33 & Baik \\
\hline $\begin{array}{l}\text { Komunika- } \\
\text { tif }\end{array}$ & 3,50 & 87,50 & $\begin{array}{c}\text { Sangat } \\
\text { baik }\end{array}$ \\
\hline $\begin{array}{l}\text { Dialogis dan } \\
\text { Interaktif }\end{array}$ & 4,00 & 100 & $\begin{array}{c}\text { Sangat } \\
\text { baik }\end{array}$ \\
\hline $\begin{array}{l}\text { Kesesuaian } \\
\text { dengan }\end{array}$ & 4,00 & 100 & $\begin{array}{c}\text { Sangat } \\
\text { baik } \\
\begin{array}{l}\text { Perkemba- } \\
\text { ngan Peserta } \\
\text { didik }\end{array}\end{array}$ \\
\hline $\begin{array}{l}\text { Kesesuian } \\
\text { dengan } \\
\text { Kaidah }\end{array}$ & 3,00 & 75 & Baik \\
\hline
\end{tabular}

\begin{tabular}{|l|c|c|c|}
\hline $\begin{array}{c}\text { Aspek yang } \\
\text { dinilai }\end{array}$ & $\begin{array}{c}\text { Rata- } \\
\text { rata } \\
\text { Validi- } \\
\text { tas }\end{array}$ & $\begin{array}{c}\text { Persenta- } \\
\text { se Vali- } \\
\text { ditas (\%) }\end{array}$ & $\begin{array}{c}\text { Kate- } \\
\text { gori }\end{array}$ \\
\hline Bahasa & & & \\
\hline Rata-rata & 3,57 & 88,64 & $\begin{array}{c}\text { Sangat } \\
\text { baik }\end{array}$ \\
\hline
\end{tabular}

Berdasarkan data uji validasi oleh ahli bahasa dapat kita lihat bahwa modul yang dikembangkan dinilai memiliki rata-rata validitas kelayakan bahasanya 3,57 dan termasuk kategori sangat baik. Modul yang dikembangkan sudah lugas ditinjau dari ketepatan struktur kalimat, kefektifan kalimat dan kebakuan penggunaan istilah. Menurut Sugihastuti (2007) kalimat yang efektif haruslah tersusun sesuai kaidah yang berlaku, sekurangkurangnya memiliki unsur subjek dan prediket. Modul yang dikembangkan juga sudah bersifat komunikatif ditinjau dari keterbacaan pesannya. Rayandra (2012) mengungkapkan bahwa sebuah modul haruslah menggunakan bahasa yang sederhana dan komunikatif.

Modul juga sudah dialogis dan interaktif dalam hal kemampuan pesan atau informasi dalam memotivasi dan mendorong peserta didik untuk berfikir kritis. Interaksi modul dengan peserta didik terlihat dalam kegiatan peserta didik melengkapi Mind map dan mengisi lembar tebak kata.

c. Data uji validitas modul oleh ahli media dapat kita lihat pada tabel berikut ini.

Tabel 3. Rata-rata Validitas Modul oleh Ahli

\begin{tabular}{|l|c|c|c|}
\hline \multicolumn{1}{|c|}{$\begin{array}{c}\text { Aspek } \\
\text { yang } \\
\text { dinilai }\end{array}$} & $\begin{array}{c}\text { Rata- } \\
\text { rata } \\
\text { Validitas }\end{array}$ & $\begin{array}{c}\text { Persentase } \\
\text { Validitas } \\
(\%)\end{array}$ & Kategori \\
\hline $\begin{array}{l}\text { Ukuran } \\
\text { Modul }\end{array}$ & 4,00 & 100 & $\begin{array}{c}\text { Sangat } \\
\text { baik }\end{array}$ \\
\hline $\begin{array}{l}\text { Desain } \\
\text { Sampul } \\
\text { Modul }\end{array}$ & 3,89 & 79,55 & $\begin{array}{c}\text { Sangat } \\
\text { baik }\end{array}$ \\
\hline $\begin{array}{l}\text { Desain } \\
\text { Isi } \\
\text { Modul }\end{array}$ & 3,95 & 98,75 & $\begin{array}{c}\text { Sangat } \\
\text { baik }\end{array}$ \\
\hline $\begin{array}{l}\text { Rata- } \\
\text { Rata }\end{array}$ & 3,95 & 98,39 & $\begin{array}{c}\text { Sangat } \\
\text { baik }\end{array}$ \\
\hline
\end{tabular}

Berdasarkan data uji validasi oleh ahli media dapat kita lihat bahwa modul yang dikembangkan dinilai memiliki rata-rata validitas kelayakan kegrafikannya 3,95 dan termasuk kategori sangat baik. Modul yang dikembangkan dinilai sudah memiliki ukuran 
fisik modul yang sangat baik. Desain sampul modul dinilai sangat baik ditinjau dari tata letak sampul, huruf yang digunakan dan ilustrasi sampul. Pada bagian sampul juga dilengkapi dengan gambar yang dapat mewakili isi modul.

Desain isi modul memiliki nilai rata-rata validitas 3,95 dan termasuk kategori sangat baik ditinjau dari konsistensi tata letak, keharmonisan unsur tata letak, kelengkapan unsur tata letak serta ilustrasi isi. Modul yang dikembangkan juga menggunakan warna dan gambar-gambar yang dapat menambah minat baca peserta didik. Menurut Ernita (2013) penggunaan grafis atau gambar yang beragam dan berwarna menimbul kan kesan menarik. Grafis atau gambar yang digunakan sesuai dengan materi yang disampai kan sehingga memudahkan peserta didik memahami materi. Kemudian Rayandra (2012) juga mengungkapkan bahwa salah satu strategi untuk dapat menarik perhatian sehingga peserta didik dapat memahami informasi penting dari modul adalah dengan memberikan warna, ukuran teks atau jenis teks yang menarik.

d. Data uji validitas modul oleh praktisi atau guru dapat kita lihat pada tabel berikut ini.

Tabel 4. Rata-rata Validitas Modul oleh Praktisi (Guru IPA SMP)

\begin{tabular}{|l|c|c|c|}
\hline $\begin{array}{c}\text { Aspek yang } \\
\text { dinilai }\end{array}$ & $\begin{array}{c}\text { Rata-rata } \\
\text { Validitas }\end{array}$ & $\begin{array}{c}\text { Persent } \\
\text { ase } \\
\text { Validi- } \\
\text { tas (\%) }\end{array}$ & $\begin{array}{c}\text { Kate- } \\
\text { gori }\end{array}$ \\
\hline $\begin{array}{l}\text { Teknik } \\
\text { Penyajian }\end{array}$ & 4,00 & 100 & $\begin{array}{c}\text { Sangat } \\
\text { baik }\end{array}$ \\
\hline $\begin{array}{l}\text { Pendukung } \\
\text { Penyajian }\end{array}$ & 4,00 & 100 & $\begin{array}{c}\text { Sangat } \\
\text { baik }\end{array}$ \\
\hline $\begin{array}{l}\text { Penyajian } \\
\text { Pembelajara } \\
\text { n }\end{array}$ & 4,00 & 100 & $\begin{array}{c}\text { Sangat } \\
\text { baik }\end{array}$ \\
\hline $\begin{array}{l}\text { Koherensi } \\
\text { dan } \\
\text { Keruntutan } \\
\text { Alur Pikir }\end{array}$ & 3,50 & 87,50 & $\begin{array}{c}\text { Sangat } \\
\text { baik }\end{array}$ \\
\hline Rata-rata & 3,88 & 96,43 & $\begin{array}{c}\text { Sangat } \\
\text { baik }\end{array}$ \\
\hline
\end{tabular}

Berdasarkan data uji validasi oleh praktisi yaitu guru dapat kita lihat bahwa modul yang dikembangkan dinilai memiliki rata-rata validitas kelayakan penyajian adalah 3,88 dan termasuk kategori sangat baik. Hal ini menunjukkan bahwa modul yang dikembangkan sudah memiliki teknik penyajian yang sangat baik ditinjau dari keruntutan konsep. Rayandra (2012) mengungkapkan bahwa dengan meng organisasikan isi materi pembelajaran dengan urutan dan susunan yang sistematis dapat memudahkan pembelajar dalam memahami materi pelajaran. Modul juga memiliki pendukung penyajian berupa kegiatan melengkapi Mind map dan tebak kata yang sangat baik.

Penyajian pembelajaran pada modul sudah melibatkan peserta didik serta memiliki koherensi dan keruntutan alur pikir dengan adanya ketertauatan antar kegiatan belajar atau sub kegiatan atau alinea serta memilki keutuhan makna dalam kegiatan belajar atau sub kegiatan atau alinea. Hal ini sesuai dengan apa yang tertuang dalam lampiran Permendikbud tahun 2016 Nomor 8 yang menjelaskan bahwa sebuah materi haruslah disajikan secara menarik (runtut, koheren, lugas, mudah dipahami, dan interaktif), sehingga keutuhan makna yang ingin disampai kan dapat terjaga dengan baik.

Berdasarkan hasil uji validasi dari 4 orang validator tersebut, dilakukanlah berberapa per baikan terhadap modul yang dikembangkan sesuai dengan komentar dan saran dari validator seperti yang tertuang pada Tabel 5 berikut ini.

Tabel 5. Komentar dan saran validator terhadap modul yang dikembangkan

\begin{tabular}{|c|l|}
\hline Aspek & \multicolumn{1}{|c|}{ Komentar/Saran } \\
\hline Materi & $\begin{array}{l}\text { Agar ditambahkan keterangan sumber } \\
\text { pada gambar }\end{array}$ \\
\hline Bahasa & $\begin{array}{l}\text { Ada beberapa penggunaan tanda baca } \\
\text { yang belum sesuai dan penulisan } \\
\text { beberapa istilah latin yang belum } \\
\text { dimiringkan }\end{array}$ \\
\hline Media & $\begin{array}{l}\text { Ada beberapa gambar pada Mind map } \\
\text { yang kurang jelas }\end{array}$ \\
\hline Praktisi & $\begin{array}{l}\text { Sebaiknya kunci jawaban dari Mind } \\
\text { map dan tebak kata ditempatkan di } \\
\text { bagian akhir modul, bukan setiap akhir } \\
\text { kegiatan belajar pada modul. }\end{array}$ \\
\hline
\end{tabular}

Berdasarkan komentar dan saran dari validator tersebut dijadikan dasar untuk merevisi modul pembelajaran yang dikembangkan diantaranya yaitu 1) Menambahkan keterangan sumber dari semua gambar pendukung yang ada pada modul; 2) memperbaiki penggunaan tanda baca yang tidak tepat dan memperbaiki penulisan istilah latin dan bahasa asing dengan format italic; 3) menggati gambar yang kurang jelas dengan gambar lain yang sesuai dan jelas dan ada juga dengan cara memperbaiki ketajaman gambar yang sudah ada; 4) 
menempatkan bagian kunci Mind map dan Tebak kata pada bagian akhir modul. Setelah dilakukan revisi, modul kembali didiskusikan dengan validator. Revisi pada modul ini dilakukan untuk penyempurnaan modul yang dikembangkan sehingga dapat dihasilkan modul pembelajaran yang valid untuk digunakan dalam proses pembelajaran.

\section{KESIMPULAN}

Berdasarkan hasil penelitian dan pem bahasan dapat disimpulkan bahwa modul Pembelajaran Biologi yang berorientasi Mind map dengan variasi tebak kata di kelas VIII SMP yang dikembangkan sudah valid dan termasuk kategori sangat baik ditinjau dari aspek kelayakan materi, kebahasaan, kegrafikan dan penyajian. Rekomendasi dari penelitian ini adalah masih perlunya penyebaran secara luas (disseminate) dari modul ini untuk menyempurnakan tahapan penelitian sesuai prosedur pengembangan Borg \& Gall.

\section{DAFTAR PUSTAKA}

Buzan, T. (2005). Buku Pintar Mind map. Jakarta : PT Gramedia Pustaka Utama.

Ella, Y. (2007). Kurikulum dan Pembelajaran, Filosofi, Teori dan Aplikasi. Jakarta : Pakar Raya.

Ernita, H. R. (2013). Pengembangan Modul Pembelajaran Cahaya dengan Pendekatan
Keterampilan Proses. Skripsi. Semarang: Universitas Negeri Semarang.

Mohammad, A. (2009). Psikologi Pembelajaran. Bandung: Wacana Prima.

Peraturan Menteri Pendidikan dan Kebudayaan Republik Indonesia Tahun 2016 Nomor 8 Tentang "Buku yang Digunakan oleh Satuan Pendidikan".

Peraturan Menteri Pendidikan dan Kebudayaan Republik Indonesia Tahun 2016 Nomor 21 Tentang "Standar Isi Pendidikan Dasar dan Menengah".

Peraturan Menteri Pendidikan dan Kebudayaan Republik Indonesia Tahun 2016 Nomor 24 Tentang "Kompetensi Inti dan Kompetensi Dasar Pelajaran pada Kurikulum 2013 pada Pendidikan Dasar dan Menengah".

Rayandra, A. (2012). Kreatif Mengembangkan Media Pembelajaran. Referensi Jakarta.

Sugihastuti. (2007). Bahasa Laporan Penelitian. Yogyakarta: Pustaka Pelajar

Taufik, T. \& Muhammadi. (2011). Mozaik Pembelajaran Inovativ. Padang : Sukabina Press.

Thiagarajan, S., Semmel, D. S \& Semmel, M. I. (1974). Instructional Development for Training Teachers of Expectional Children. Minneapolis, Minnesota: Leadership Training Institute/Special Education, University of Minnesota. 